Siti Mabmudah Noorbayati

\title{
MEKANISME KULTURAL SEBAGAI COUNTER- RADIKALISME: Mengurai Narasi Terorisme Muslim Sasak di Nusa Tenggara Barat (NTB)
}

Institut Agama Islam Nasional La Roiba, Bogor

Email: mahmudahnoorhayati@gmail.com

\footnotetext{
Received:

2020-06-09

Received in revised form:

2020-06-13

Accepted:

2020-06-24

Citation:

Noohayati, Siti

Mahmudah (2020),

Mekanisme Kultural

Sebagai Counter-

Radikalisme: Mengurai

Narasi Terorisme Muslim

Sasak di Nusa Tenggara

Barat (NTB), 7(1), 16-

29.
}

\begin{abstract}
The idea of intensification of cultural mechanisme is based on an innitiative to strenghten narration of local islam as mediation between moderate, radical, and militant groups in West Nusa Tenggara (NTB) in which most of the inhabitants are Sasak. Muslim. This article attempts to trace the possible implementation of cultural mechanisme as a responsive effort to the narration of radicalism among moderate people in NTB. This study also analyze a construction of terrorism and radicalism narration, types of their acceptances and diffusions in ntb, then build a formulated recommendations for dealing with these issues.
\end{abstract}

Keywords: Cultural Mechanism, Counter-Radicalism, Narration of Terrorism, West Nusa Tenggara 


\begin{abstract}
Abstrak: Gagasan mengenai intensifikasi mekanisme kultural labir dari keinginan untuk memperkuat narasi Islam lokal sebagai mediasi antara kelompok moderat, radikal, dan militan di kawasan Nusa Tenggara Barat yang mayoritas bersuku Sasak Muslim. Artikel ini melacak kemungkinan diterapkannya mekanisme kultural tersebut dalam merespons potensi kuatnya narasi radikalisme di tengah-tengah masyarakat yang mayoritas berwawasan moderat. Artikel ini juga menganalisis konstruksi narasi terorisme dan radikalisme, pola penerimaan, dan penyebarannya di NTB, lalu berusaha merumuskan rekomendasi-rekomendasi yang dapat menjadi solusi atas isu tersebut.
\end{abstract}

Kata kunci: Mekanisme Kultural, Counter-Radikalisme, Narasi Terorisme, Nusa Tenggara Barat

\title{
PENDAHULUAN
}

Nusa Tenggara Barat (NTB) dengan ibu kota Mataram terkenal dengan masyarakat yang memegang teguh Ahlusunnah wal Jamaah (Aswaja). Mereka umumnya menggunakan fiqih sebagai landasan ketetapan hukum bagi kehidupan beribadah, sosial, dan muamalah. Paham Aswaja ini merupakan karakteristik komunitas Nahdlatul Ulama (NU), yang menjadi basis ideologi Muslim Sasak. $^{1}$

Hampir semua masyarakat NTB bersuku Sasak. Hanya sebagian kecil yang masih dikategorikan sebagai Sasak Boda (masyarakat Mataram kuno yang masih mempercayai kepercayaan dinamisme dan animisme). ${ }^{2}$ Selain mayoritas beragama Islam, Suku Sasak juga dikenal sebagai masyarakat yang memegang nilai-nilai Islam lokal. Dari sinilah, muncul beberapa aliran keagamaan, seperti Islam wetu telu, wetu lima, Nahdah Al-Wathan, dan bahkan Ahmadiyah. ${ }^{3}$

Meskipun nilai-nilai lokal cenderung menjadi perekat solidaritas antarsesama suku, narasi radikalisme dan terorisme bukan berarti tidak berkembang dalam masyarakat NTB. Narasi-narasi radikal semacam ini umumnya terlihat di kawasan-kawasan seperti Bima, Sumbawa, Lombok

\footnotetext{
1 Saeful Muzani, Islam Rasional: Gagasan dan Pemikiran Harun Nasution, (Bandung: Mizan, 1995), 160; bdk. Ahmad Amir Aziz, "Islam Sasak: Pola Keberagamaan Komunitas Islam Lokal di Lombok," Millah: Jurnal Studi Agama, 8(2), 2009: 241-253.

${ }^{2}$ Erni Budiwanti, "The Impact of Islam on the Religion of the Sasak in Bayan, West Lombok." Kultur, 1(2), 2001: 30 .

${ }^{3}$ Erni Budiwanti, Islam Sasak: Wetu Telu versus Waktu Lima, (Yogyakarta: LkiS, 2000), 6.
} 
Timur, dan Mataram. Kelompok yang intensif mengusung corak pemikiran ini bisa dilacak pada jaringan-jaringan seperti Hizbut Tahrir Indonesia, Jamaah Anshorut Tauhid, dan Majelis Mujahidin Indonesia.

Pesantren Darus Syifa, dalam hal ini, bisa dikatakan sebagai lembaga yang paling aktif mengampanyekan narasi radikalisme. Berbasis di Tripas, Korleko, Lombok Timur, pesantren yang lebih dikenal dengan pesantren Abu Jibril ini sesuai dengan pendirinya Abu Jibril (alias Ust. H. Fihirudin) dan saudaranya Ust. H. M. Musfri, salah satu tersangka kasus teroris di Pamulang Tangerang Banten beberapa tahun lalu. Dengan misi ala minhaj al-nubunwah, pesantren yang terdiri dari 350-an santri ini berfokus—salah satunya—pada peningkatan semangat untuk siap harta dan jiwa demi jihad fi sabilillah.

Selain narasi radikal tersebut, kondisi Islam di NTB juga diwarnai dengan munculnya beragam organisasi Islam. Kemunculan ini disebabkan oleh beberapa faktor, antara lain: daya lentur ajaran Islam, kompatibilitas nilainilai Islam dengan segala aspek kehidupan manusia, potensi Islam yang kuat dalam melawan segala bentuk kekuasaan, dan-yang paling pentingkemudahan Islam untuk berasimiliasi dengan nilai-nilai lokal. ${ }^{4}$

Kondisi sosio-religius di atas tak pelak melahirkan setidak-tidaknya empat kelompok besar Islam di NTB, yakni kelompok modernis (yang diwakili oleh Muhammadiyah dan Wahabiah), kelompok tradisional (seperti Nahdlatul Wathan [NW] dan Nahdlatul Ulama' [NU]), kelompok radikalis (misalnya, HTI, MMI, dan seterusnya), dan kelompok minoritas (seperti Islam wetu telu dan Ahmadiyah).

Selain empat kelompok di atas, ada pula individu-individu yang turut menentukan perkembangan narasi Islamisme di NTB. Mereka dikenal sebagai "tuan guru", yang dalam terminologi suku Sasak di NTB, memiliki kesamaan dengan sebutan "kiai haji” di suku Jawa. Di NTB juga dikenal kiai haji, namun

\footnotetext{
${ }^{4}$ Fathurrahman Zakaria, Mozaik Budaya Mataram, Mataram: Yayasan Sumurmas Al-Hamidy, 1998), 46. 
dalam beberapa hal tuan guru memiliki lebih banyak otoritas dibanding kiai haji, tidak hanya di level religius dan politik, melainkan juga di level personal. ${ }^{5}$

Artikel ini menawarkan hasil riset terkait dengan konstruksi narasi Islamisme di NTB. Studi ini berfokus pada upaya memetakan pola-pola narasi yang berkembang di NTB menyangkut narasi pluralisme aliran, Amerika dan Yahudi, Islam liberal, Khilafah vs NKRI, radikalisme dan terorisme, serta jihad. Pertanyaan awal yang akan didiskusikan adalah bagaimana konstruksi, pola penyebaran, dan pola penerimaan narasi-narasi tersebut berkembang di NTB?

\section{METODE}

Riset terhadap konstruksi narasi dan pola penyebaran serta penerimaannya di NTB ini memanfaatkan berbagai sumber data dari para informan, yang terbagi ke dalam 8 kategori subjek penelitian, antara lain: Remaja Mushalla (di SMAN 1 Mataram, SMAN 5 Mataram, SMKN 2 Mataram, dan MAN 1 Mataram), Lembaga Dakwah Kampus (di IAIN Mataram, IKIP Mataram, dan Universitas Mataram), Kelompok Pemuda (Himpunan Mahasiswa Nahdlatul Wathan [HIMMA NW], Keluarga Mahasiswa Islam Bima [GAMAIS], Pemuda Bima, Pemuda Sumbawa, dan Komite Nasional Pemuda Indonesia [KNPI), Politisi (Wakil Ketua DPRD NTB, Ketua DPW PKS, Ketua DPW PKB, Ketua DPW PPP, Wakil Ketua Partai Demokrat, dan Ketua DPW PAN NTB), Pemuda Masjid (Masjid Raya Mataram, Masjid Universitas Mataram, Masjid Mujahidin Cakra Mataram, dan Masjid Dinas Kesehatan Mataram), Däi/Khatib, dan Tokoh Agama.

Riset ini dilaksanakan dalam satu bulan penuh (awal hingga akhir Juli 2018). Karena fokusnya terhadap narasi terorisme, riset ini berkonsentrasi pada life story para informan dengan teknik wawancara dan observasi lapangan. Pendekatan yang digunakan adalah etnografis dan naratif. Narasi dipilih

\footnotetext{
${ }^{5}$ Bahruddin, Nahdlatul Wathan dan Perubahan Sosial, (Yogyakarta: Genta Press, 2007), 65-66.
} 
sebagai objek sekaligus pendekatan karena hingga saat ini pola-pola semacam inilah yang jarang dieksplorasi dalam sekian banyak agenda kebijakan terorisme di Indonesia, padahal narasi merupakan sekumpulan cerita yang dapat menjelaskan peristiwa-peristiwa 'alamiah' yang berkembang di masyakarat, karena ia terkonstruksi dari gagasan-gagasan dan pemikiranpemikiran yang sudah ada di sana. ${ }^{6}$

Proyek ini melibatkan tiga komponen utama, yakni (1) pemetaan konstruksi narasi yang sifatnya problematik dan solutif; (2) pemetaan pola penyebaran narasi; dan (3) pemetaan pola penerimaan narasi.

\section{TEMUAN}

\section{PERSEBARAN NARASI RADIKALISME DI NUSA TENGGARA BARAT}

Temuan utama dari komponen kualitatif ini-berdasarkan data yang dikumpulkan dari para informan yang berasal dari berbagai afiliasi sosiopolitik-keagamaan di

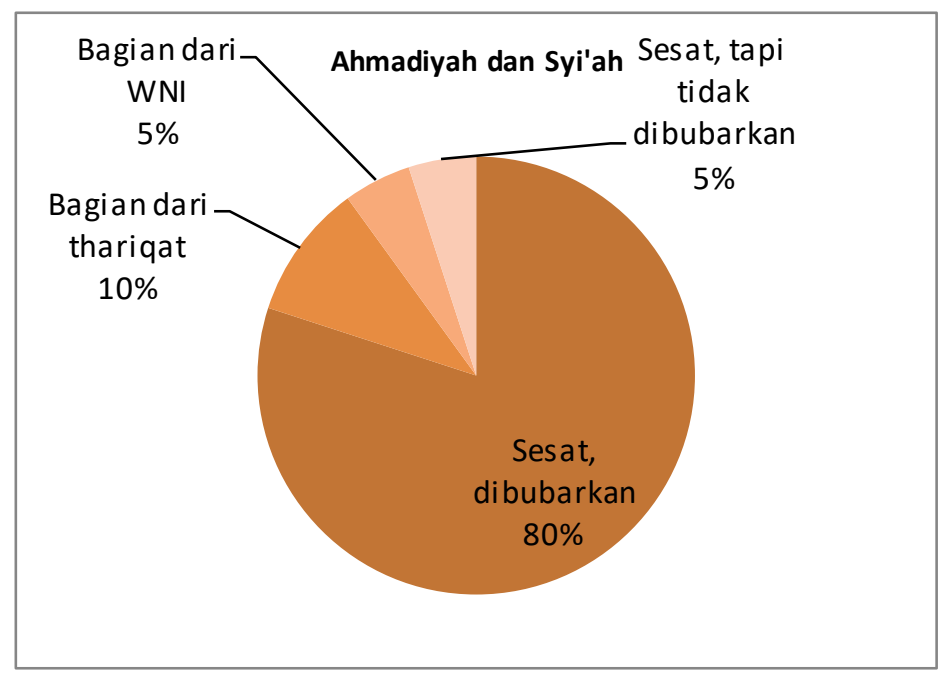

Gambar 1 Pola penyebaran narasi tentang Ahmadiyah dan Syiah

NTB—adalah sebagai berikut:

Mengenai isu pluralisme aliran, yang melibatkan Ahmadiyah dan Syiah, hampir semua responden sepakat untuk menolaknya. Alasannya beragam: mulai dari anggapan bahwa kedua aliran tersebut telah menyimpang dari syariat, hingga penilaian yang menuding

\footnotetext{
${ }^{6}$ David Betz, "The Virtual dimension of Contemporary Insurgency and Counterinsurgency," Small Wars \& Insurgencies, 19(4), 2008: 515; bdk. Lawrence Freedman, The Transformation of Strategic Affairs, (London: The International Institute for Strategic Studies, 2006), 22.

At-Turäs: Jurnal Studi Keislaman

E-ISSN: 2460-1063, P-ISSN: 2355-567X

Volume 7, No. 1, Januari-Juni 2020
} 
Syiah mirip dengan Yahudi. Akan tetapi, sebagian yang lain menerima kedua aliran sebagai bagian dari thariqat Islam atau menganggapnya bagian dari NKRI yang harus dihormati. Ada pula yang menolaknya secara halus dengan mengatakan bahwa pembubaran tidak boleh dilakukan, tetapi bukan berarti kedua aliran tersebut lepas dari label "sesat."

Terkait opini tentang Amerika dan Yahudi, narasi yang berkembang lebih variatif, namun mayoritas masyarakat NTB masih menolak keduanya dengan berbagai alasan. Yang menolak umumnya memiliki alasan sebagai berikut: Amerika adalah misionaris Kristen, Yahudi merupakan musuh Islam sebagaimana yang disebut dalam Al-Quran, kebijakan Amerika selalu merugikan negara-negara Islam, dan sebagainya. Sementara itu, yang

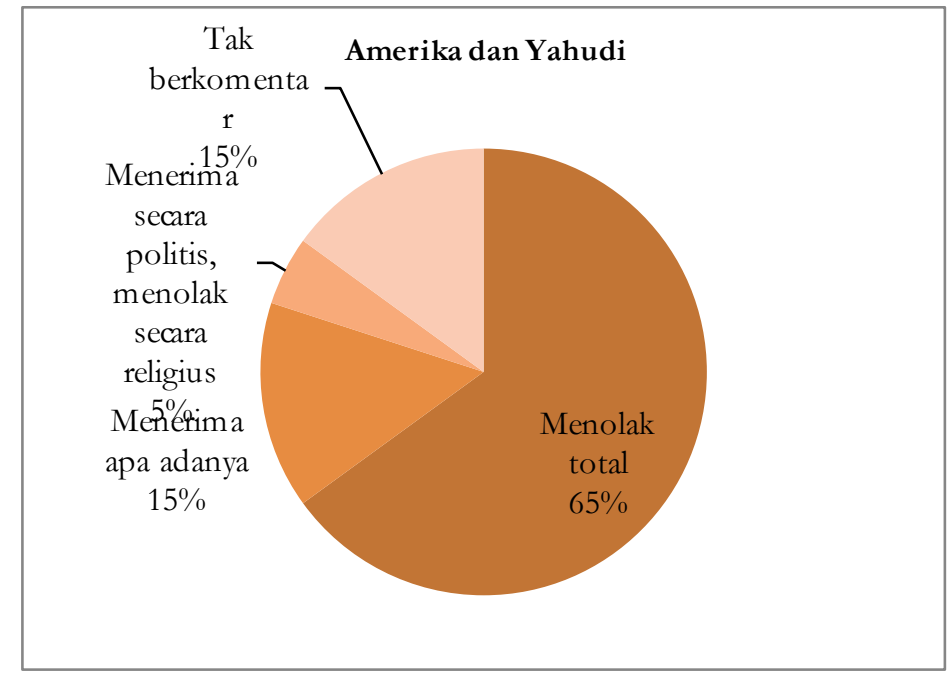

Gambar 2 Pola penyebaran narasi tentang Amerika dan Yahudi mendukung Amerika dan Yahudi berargumen bahwa keduanya memiliki nilai toleransi dan tingkat kecerdasan yang tinggi dibanding negara-negara lain, dan karenanya Indonesia harus belajar dari mereka. Akan tetapi, banyak pula yang melihat

keduanya secara "diplomatik" dengan alasan: dari sisi politik Amerika dan Yahudi jelas lebih unggul, namun dari sisi hubungan internasional dengan negara-negara Islam mereka lebih sering merugikan; Amerika dan Yahudi harus dilawan secara kritis dan cerdas, bukan antagonistik. Meski demikian, yang unik adalah bahwa tidak sedikit pula yang lebih memilih untuk tidak berkomentar apa-apa tentang keduanya. 
Tentang radikalisme dan terorisme, bisa dikatakan bahwa hampir semua masyarakat NTB menolak keduanya. Meski demikian, ada sebagian responden yang membedakan terorisme dari radikalisme.

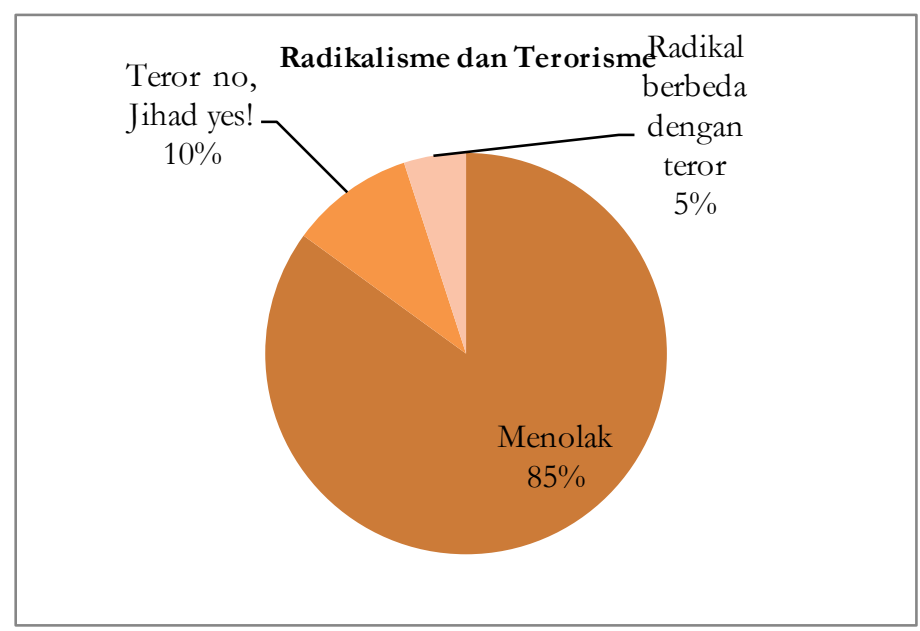

Bagi mereka, gerakan Gambar 3 Pola penyebaran narasi tentang radikalisme dan terorisme radikal yang ditunjukkan FPI sah-sah saja, sementara aksi teror bom Bali tidak bisa dibenarkan. Radikalisme, bagi mereka, lebih terkait dengan pemikiran dibanding tindakan (teror). Hal ini juga menuntun pada pandangan mereka yang umumnya mengaitkan teror dengan konsep jihad dalam Islam, sebagaimana yang akan dijelaskan kemudian.

Berkaitan dengan Islam liberal, narasi yang berkembang umumnya menunjukkan ketidaksepakatan masyarakat terhadap gerakan tersebut. Ada banyak alasan yang melatarbelakangi sikap antipati mereka terhadap Islam liberal, antara lain, karena ideologi ini dianggap sebagai ancaman kehancuran umat Islam, musuh Islam dari dalam, aliran yang kebablasan, bahkan sebagai bagian dari politik Amerika dan Yahudi. Meski demikian, ada pula sebagian responden yang melihat Islam liberal justru sebagai sebentuk ijtihad progresif yang harus dihormati. Di pihak lain, kalangan politisi, lebih acuh tak acuh; menganggap Islam liberal bukan isu penting yang harus dibicarakan.

Mengenai isu Khalifah dan NKRI, narasi yang berkembang lebih variatif. Di kalangan politisi, NKRI adalah harga mati, dan Pancasila sudah sesuai dengan nilai-nilai Islam. Bagi kalangan LDK kampus, sudah saatnya NKRI diganti dengan sistem khilafah yang dianggap lebih menjanjikan. Sementara itu, di kalangan pelajar, terdapat perbedaan sikap: MAN 2 Mataram 
mendukung khilafah, namun SMAN 1 Mataram menganggap khilafah hanyalah alternatif dari NKRI.

Tentang narasi jihad, opini yang berkembang menunjukkan penolakan masyarakat terhadapnya. Meski demikian, muncul pula kecenderungan kuat

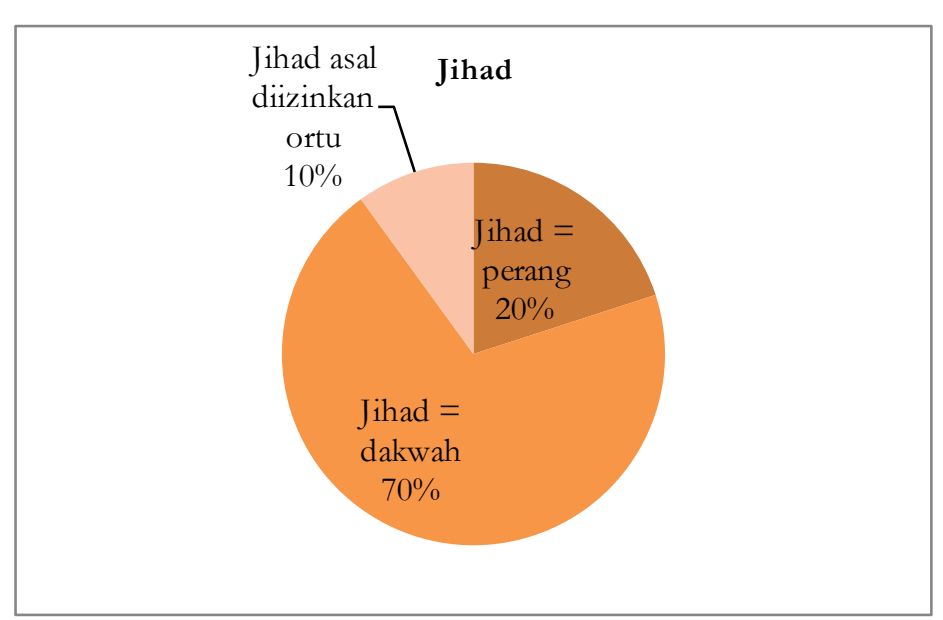
untuk mengaitkan jihad dengan terorisme dan radikalisme. Sebanyak 2 dari 3 LDK, termasuk GAMIS, setuju pada jihad, dan mereka secara terangterangan bersedia jika

Gambar 4 Pola penyebaran narasi tentang jihad

diminta untuk berjihad (baca: berperang). Di kalangan tokoh agama dan politisi, jihad dimaknai dalam konteks dakwah, bukan perang. Sementara itu, di kalangan pelajar, konsep jihad masih belum terumuskan dengan jelas. Hal ini terlihat dari alasan yang umumnya disampaikan pelajar: bahwa mereka mau berjihad asal diizinkan oleh orang tua. 


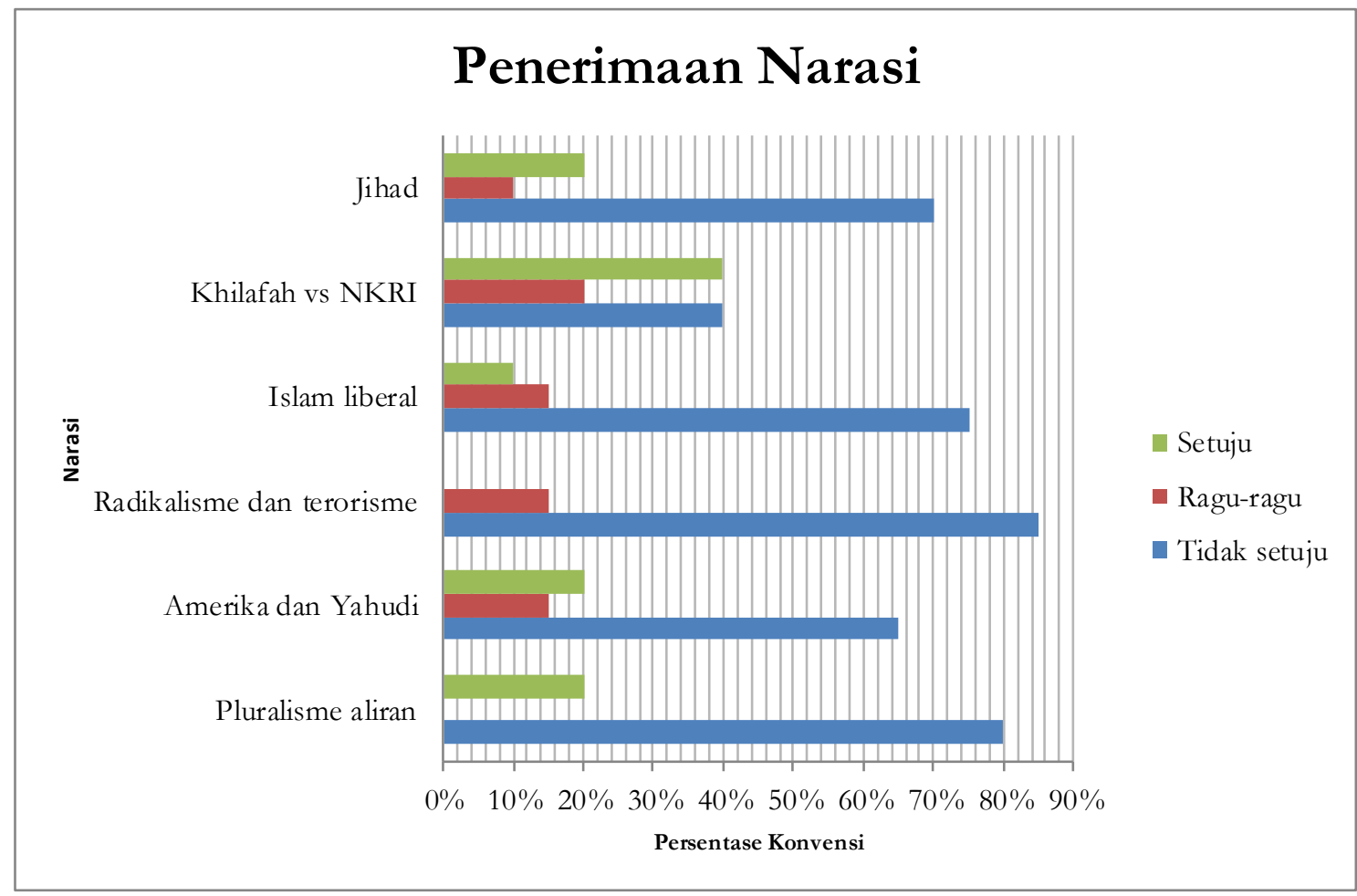

Gambar 5 Pole penerimaan narasi terorisme dan radikalisme di Nusa Tenggara Barat

Pola penyebaran narasi terorisme di NTB umumnya dilakukan melalui masjid, organisasi kemasyarakatan, dan media massa. Yang menggunakan masjid sebagai tempat penyebaran narasi utamanya adalah LDK-LDK Kampus. Untuk media, narasi terorisme lebih sering tersebar di stasiun-stasiun TV lokal, seperti TV 9 dan ANTI Lombok melalui para da’i. Selain itu, majalah dinding, buletin, dan diskusi rutin oleh organisasi kepemudaan, LDK, dan Remus juga menjadi sarana aktif penyebaran narasi tersebut.

Pola penerimaan narasi terorisme di NTB bisa dibedakan dalam tiga kategori besar, yakni moderat, militan, dan radikal. Di kalangan moderat dapat ditemukan tokoh, tokoh masyarakat, satu organisasi pemuda (HIMMA NW), dan para politisi, yang sebagian besar menerima perbedaan sebagai suatu hal yang wajar dan patut dikelola dengan baik. Pola penerimaan yang bercorak militan bisa dilacak pada opini para pelajar dan pemuda, meski ada sedikit tokoh agama, yang umumnya memahami ajaran Islam secara tekstualis, menolak Ahmadiyah dan Syi'ah, serta antipati terhadap Amerika dan Yahudi. 
Sementara itu, masuk dalam kategori radikal adalah LDK UNRAM, LDK IKIP Mataram, GAMAIS, Pemuda Bima, dan PII yang melihat Islam tidak hanya dalam konteks religius, melainkan juga politis. Untuk itulah, narasi yang berkembang di kalangan mereka memperlihatkan sikapnya yang sangat ideologis terhadap khilafah dan meyakini syariat Islam sebagai aturan terbaik bagi sistem pemerintahan Indonesia.

Faktor-faktor penyebaran dan penerimaan narasi tersebut dapat dibagi ke dalam tiga aspek: doktrin agama, lingkungan sosio-budaya, dan ideologi Islamisme. Masyarakat Sasak umumnya sudah memiliki kebudayaan lokal tersendiri sebelum menerima ajaran agama. ${ }^{7}$ Masuknya agama Islam membuat mereka harus mengkompromikan doktrin ajaran agama tersebut dengan nilainilai lokal. Tak heran di lingkungan Sasak, yang mayoritas berhaluan Aswaja, memiliki tradisi-tradisi yang hingga saat ini masih dipertahankan, seperti tradisi Srakalan Haji, Ziarah Haji, Merarik, dan sebagainya. ${ }^{8}$ Akan tetapi, hal ini tidak lantas membuat ideologi-ideologi Islamisme menyusut. Keberadaan HTI, JT, MMI, dan organisasi-organisasi keagaman sejenis menjadi bukti bahwa masyarakat NTB juga memiliki basis ideologi Islamisme yang cukup kuat, di samping organisasi-organisasi besar seperti NU dan Muhammadiyah. Faktorfaktor inilah yang membuat narasi terorisme menjadi beragam sekaligus rentan di masyarakat NTB. ${ }^{9}$

\section{PEMBAHASAN \\ MEKANISME KULTURAL IDEOLOGIS SEBAGAI REKOMENDASI}

Isu terorisme yang tidak didukung oleh hampir semua elemen masyarakat NTB memperlihatkan kabar gembira bagi penanganan isu

\footnotetext{
${ }^{7}$ M. Mutawali \& M. H. Zuhdi, "Genealogi radikalisme-terorisme di Provinsi Nusa Tenggara Barat”, Laporan Penelitian, (Mataram: UIN Mataram, 2017), 54.

${ }^{8}$ Nazar Naamy, "Revitalisasi Krame Banjar dalam Menangkal Wacana Radikalisme di Lombok Barat." Tasâmuh, 15(2), 2018: 83-100.

${ }^{9}$ N. N. Adilansyah, Aini Annisya, \& Adi Hidayat Argubi, "Kajian Perubahan Perilaku Individu Biasa Menjadi Teroris," Jurnal Komunikasi dan Kebudayaan, 5(2), 2018: 1-22.
} 
terorisme di masyarakat, namun masih dibutuhkan upaya lebih serius untuk terus menyuburkan narasi-narasi semacam ini untuk generasi mendatang. Ada kecenderungan kuat dalam memahami terorisme dalam kaitannya dengan jihad, sehingga upaya untuk meminimalisasi narasi-narasi soal jihad, utamanya di lingkungan LDK dan Remus, perlu digalakkan.

Asimilasi nilai-nilai lokal dengan doktrin agama memperlihatkan daya lentur masyarakat NTB dalam memahami isu-isu agama, namun masih suburnya ideologi Islamismenya dan aktivismenya di level organisasiorganisasi tertentu membutuhkan upaya yang lebih serius untuk mengimbanginya dengan mekanisme-mekanisme kultural. ${ }^{10}$ Kalangan pelajar sudah cukup kritis dalam memahami narasi-narasi terorisme yang berkembang, namun mereka masih rentan terjebak kebimbangan dalam memaknai jihad, sehingga dibutuhkan strategi-strategi pedagogis yang memungkinkan mereka memahami jihad dalam kerangka yang lebih bijak. ${ }^{11}$

Kelompok-kelompok moderat seperti NU dan Muhammadiyah yang menjadi basis utama dalam kehidupan religius-kultural masyarakat NTB merupakan gejala postif, namun tetap memerlukan pertimbangan serius mengimbangi kemunculan kelompok-kelompok militan dan radikal yang sudah mulai menjamur. Tokoh agama dan tokoh masyarakat umumnya memberi respons positif terhadap bahaya terorisme dan radikalisme, namun hal ini hanya terjadi dalam skala kultural, namun jarang sekali terlihat dalam level-level yang sifatnya lebih struktural. ${ }^{12}$

Dari uraian tentang penyebaran dan penerimaan narasi terorisme dan radikalisme di Nusa Tenggara Barat di atas, dapat diketahui bahwa pada

\footnotetext{
${ }^{10}$ Muhammad Harfin Zuhdi, "Potential Islamic Radicalism and Terrorism in the Province of West Nusa Tenggara," AHKAM: Jurnal Ilmu Syariah, 19(1), 2019: 24.

11 Zusiana Triantini, dkk. Laporan Penelitian: Narasi dan Politik Identitas. Pola Penyebaran dan Penerimaan Radikalisme dan Terorisme di Nusa Tenggara Barat (Yogyakarta: BNPT, FKPT, dan Fakultas Syariah dan Hukum UIN Sunan Kalijaga, 2013), 34-65.

12 Nurul Faiqah \& Toni Pransiska, "Radikalisme Islam vs Moderasi Islam: Upaya Membangun Wajah Islam Indonesia yang Damai," Al-Fikra, 17(1), 2018: 33-60.

At-Turäs: Jurnal Studi Keislaman

E-ISSN: 2460-1063, P-ISSN: 2355-567X

Volume 7, No. 1, Januari-Juni 2020
} 
hakikatnya NTB membutuhkan suatu mekanisme kultural untuk memperkuat upaya counter-narasi terorisme di wilayah tersebut. Mekanisme tersebut bisa dilakukan dengan beberapa cara.

Pertama, baik media cetak maupun elektronik perlu menampilkan narasinarasi yang lebih intensif dalam penolakannya terhadap isu terorisme dan radikalisme di masyarakat melalui siaran-siaran yang lebih mengedepankan isuisu perdamaian dibanding isu konflik dan perpecahan.

Kedua, dibutuhkan upaya pelembagaan jejaring pemuda yang berfokus pada penanaman nilai-nilai peace building, agar pemuda (utamanya para pelajar) dapat memetakan lebih jelas isu-isu yang mereka hadapi dan temui di luar sekolah, utamanya yang menyangkut narasi jihad dan aliran sesat.

Ketiga, sebagai kelompok mayoritas, organisasi-organisasi moderat, seperti NU dan Muhammadiyah, perlu lebih intensif dalam merangkul dan berdialog dengan kelompok-kelompok radikal dan militan untuk menghidupkan suasana yang harmonis serta mengembangkan programprogram struktural yang dapat memungkinkan kedua belah pihak terus berdialog dan berkonsolidasi, alih-alih membicarakan dan menggunjing satu sama lain di internal organisasi masing-masing.

Keempat, tradisi-tradisi lokal yang berkembang di masyarakat NTB harus dipertahankan dan ditingkatkan keberlanjutannya sebagai pemersatu kultural masyarakat NTB di saat organisasi-organisasi keagamaan kurang mampu menjalankan tugas kolaboratifnya dengan baik.

Kelima, kontrol terhadap lembar-lembar Jum'at atau media-media elektronik lain yang lebih sering menampilkan narasi-narasi radikal merupakan suatu keniscayaan, dan-jika perlu_- “diimbangi” melalui penyebaran mediamedia serupa yang mengkontra narasi-narasi tersebut.

Keenam, lembaga-lembaga lintas-agama dan/atau lintas-etnik, baik yang berada di bawah naungan pemerintah, yayasan, maupun sukarela, perlu 
didukung oleh seluruh elemen masyarakat (utamanya perangkat desa) untuk mengizinkan terlaksananya program yang diinisiasi oleh lembaga-lembaga itu.

\section{PENUTUP}

Gagasan mengenai intensifikasi mekanisme kultural lahir dari keinginan untuk memperkuat narasi Islam lokal sebagai mediasi antara kelompok moderat, radikal, dan militan di kawasan Nusa Tenggara Barat yang mayoritas bersuku Sasak Muslim. Artikel ini telah berhasil melacak kemungkinan diterapkannya mekanisme kultural tersebut dalam merespons potensi kuatnya narasi radikalisme di tengah-tengah masyarakat yang mayoritas berwawasan moderat. Artikel ini juga telah berhasil menganalisis konstruksi narasi terorisme dan radikalisme, pola penerimaan, dan penyebarannya di NTB, lalu berusaha merumuskan rekomendasi-rekomendasi yang dapat menjadi solusi atas isu tersebut. Ke depan, upaya rekonsiliasi melalui mekanisme prosedural, bukan semata-mata kultural, juga diperlukan untuk memperkuat jejaring penerimaan narasi moderat di NTB. 


\section{DAFTAR PUSTAKA}

Adilansyah, N. N., Aini Annisya, dan Adi Hidayat Argubi. (2018). "Kajian Perubahan Perilaku Individu Biasa Menjadi Teroris," Jurnal Komunikasi dan Kebudayaan, 5(2), 1-22.

Aziz, Ahmad Amir. (2009). "Islam Sasak: Pola Keberagamaan Komunitas Islam Lokal di Lombok," Millah: Jurnal Studi Agama, 8(2), 241-253.

Bahruddin. (2007). Nabdlatul Wathan dan Perubahan Sosial, Yogyakarta: Genta Press.

Betz, David. (2008). "The Virtual dimension of Contemporary Insurgency and Counterinsurgency," Small Wars \& Insurgencies, 19(4), 510-540.

Budiwanti, Erni. (2001). "The Impact of Islam on the Religion of the Sasak in Bayan, West Lombok," Kultur, 1(2), 34-67.

Budiwanti, Erni. (2000). Islam Sasak: Wetu Telu versus Waktu Lima, Yogyakarta: LkiS.

Faiqah, Nurul, and Toni Pransiska. (2018). "Radikalisme Islam vs Moderasi Islam: Upaya Membangun Wajah Islam Indonesia yang Damai," AlFikera, 17(1), 33-60.

Freedman, Lawrence. (2006). The Transformation of Strategic Affair, London: The International Institute for Strategic Studies.

Mutawali, M., \& Zuhdi, M. H. (2017). "Genealogi radikalisme-terorisme di Provinsi Nusa Tenggara Barat." Laporan Penelitian, Mataram: UIN Mataram.

Muzani, Saeful. (1995). Islam Rasional: Gagasan dan Pemikiran Harun Nasution. Bandung: Mizan.

Naamy, Nazar. (2018). "Revitalisasi Krame Banjar dalam Menangkal Wacana Radikalisme di Lombok Barat," Tasâmuh, 15(2), 83-100.

Triantini, Zusiana E., dkk. (2013). Laporan Penelitian: Narasi dan Politik Identitas. Pola Penyebaran dan Penerimaan Radikalisme dan Terorisme di Nusa Tenggara Barat. Yogyakarta: BNPT, FKP', dan Fakultas Syariah dan Hukum UIN Sunan Kalijaga.

Zakaria, Fathurrahman. (1998). Mozaik Budaya Mataram. Mataram: Yayasan Sumurmas Al-Hamidy.

Zuhdi, Muhammad Harfin. (2019). "Potential Islamic Radicalism and Terrorism in the Province of West Nusa Tenggara," AHKAM: Jurnal Ilmu Syariah, 19(1),: 23-75. 